УДК 811.111

DOI 10.23951/2307-6127-2020-2-100-112

\title{
РАЗВИТИЕ ИНОЯЗЫЧНОЙ КОММУНИКАТИВНОЙ КОМПЕТЕНЦИИ У СТУДЕНТОВ НЕЯЗЫКОВЫХ НАПРАВЛЕНИЙ С ИСПОЛЬЗОВАНИЕМ АССОЦИАТИВНО-ПРОЕКТНОГО МЕТОДА
}

\author{
Г. Н. Кукарская, В. М. Пахомова, И. С. Трифонова
}

Тюменский государственный университет, Тюмень

\begin{abstract}
Обозначена основополагающая тенденция в обучении иностранному языку - коммуникативная. Ставится проблема поиска эффективных методов обучения студентов неязыковых специальностей навыкам говорения на иностранном языке. В качестве решения поставленной задачи предлагается рассмотреть целесообразность применения ассоциативно-проектного метода на занятиях по английскому языку у студентов неязыковых специальностей. Исследование проводилось в три этапа. Первый этап предполагал опрос студентов неязыковых специальностей об основных трудностях при говорении на английском языке. В опросе приняли участие 97 студентов Тюменского государственного университета. Второй этап базировался на проведении экспериментальной серии занятий с применением ассоциативно-проектного метода. На данном этапе было задействовано 44 студента трех групп с языковыми уровнями Elementary (элементарный), Pre-Intermediate (ниже среднего) и Intermediate Low (средний низкий). На заключительном этапе эти же студенты прошли финальный опрос об эффективности применения данного метода в преодолении основных трудностей при говорении на английском языке. Анкетирование студентов неязыковых специальностей с последующим ранжированием полученных данных позволило на первом этапе исследования установить три основные трудности при говорении. Эти коммуникативные барьеры носят как лингвистический, так и экстралингвистический характер. Применение ассоциативнопроектного метода на занятиях по английскому языку позволило, как показал финальный опрос студентов, в значительной степени преодолеть эти трудности. Ассоциативно-проектный метод представляет собой сочетание двух достаточно новых и актуальных методов (ассоциативного и проектного), применяемых в обучении иностранному языку. Он удовлетворяет современным требованиям образования, способствует формированию ключевых компонентов коммуникативной компетенции (языкового, речевого, социолингвистического и социокультурного) и позволяет справиться с основными барьерами при говорении на иностранном языке.
\end{abstract}

Ключевые слова: иноязычная коммуникативная компетенция, коммуникативные барьеры, ассоциативно-проектный метод, ассоциация, анкетирование.

В настоящее время российское высшее образование продолжает претерпевать существенные изменения, касающиеся, прежде всего, повышения качества подготовки будущих специалистов. На сегодняшний день общепризнанным считается утверждение о том, что конкурентоспособный специалист любого профессионального направления должен обладать хорошими знаниями иностранного языка. Чаще всего речь идет об английском языке как о международном рабочем языке всех конференций, симпозиумов, семинаров, проектов, соревнований, бизнеса и т. д. В основе всех этих форм человеческого взаимодействия лежит коммуникация на иностранном языке. Коммуникативная направленность сегодня является основополагающим принципом обучения иностранному языку в высшей школе и предполагает развитие иноязычной коммуникативной компетенции. 
Принято считать, что впервые в отечественное научное сообщество термин «коммуникативная компетенция» был введен М. Н. Вятютневым и определялся как «выбор и реализация программ речевого поведения в зависимости от способности человека ориентироваться в той или иной обстановке общения; умение классифицировать ситуации в зависимости от темы, задач, коммуникативных установок, возникающих у учеников до беседы, а также во время беседы в процессе взаимной адаптации» [1, с. 38]. Впоследствии в процессе разностороннего и многоаспектного изучения коммуникативной компетенции, в частности иноязычной коммуникативной компетенции, это понятие претерпело различные изменения. В результате в трудах большинства отечественных исследователей иноязычная коммуникативная компетенция определяется как «способность и готовность к иноязычному общению с носителями языка, восприятию и пониманию партнеров, адекватному и своевременному выражению своих мыслительных намерений» [2, с. 84].

Следует отметить, что проблемами формирования и овладения иноязычной коммуникативной компетенцией в разное время занимались такие отечественные и зарубежные ученые, как П. Бергер [3], Дж. Борден [4], И. Л. Бим [5], Н. И. Гез [6], Н. В. Елизарова [7], И. А. Зимняя [8], Е. И. Пассов [9], С. Савиньон [10], В. В. Сафонова [11], Д. Хаймс [12], А. Н. Щукин [13] и др.). Кроме того, на сегодняшний день известно достаточно много классификаций, определяющих структуру иноязычной коммуникативной компетенции. Среди них можно выделить работы таких ученых, как П. Дуайе [14], Л. Бахман [15], С. Савиньон [10], Р. П. Мильруд [16]. Все существующие классификации, по мнению Н. П. Таюрской, можно объединить в две большие модели: общеевропейскую и российскую. Российская структурная модель иноязычной коммуникативной компетенции включает следующие компоненты: языковую, речевую, социокультурную, компенсаторную, учебно-познавательную, Общеевропейская модель - лингвистическую, социолингвистическую, социокультурную, дискурсивную, стратегическую, социальную компетенции [2, с. 84]. Тем не менее первоначально, как отмечает Е. Н. Гром, к числу ключевых компонентов иноязычной коммуникативной компетенции все ученые относили языковую (обозначаемую в общеевропейской модели как лингвистическая компетенция) и речевую (дискурсивная в общеевропейской модели), а также социокультурную и социолингвистическую компетенции [17]. Языковая компетенция считается основным компонентом коммуникативной компетенции, поскольку без знания слов немыслима коммуникация. С ней тесно связана речевая компетенция как умение свободно выражать свои мысли на иностранном языке. Социолингвистическая компетенция предполагает умение подбирать необходимую лингвистическую форму в зависимости от ситуации, а социокультурная отвечает за фоновые знания говорящего об иноязычной культуре.

Как показывает опыт преподавания у студентов неязыковых специальностей, овладение навыками говорения на иностранном языке вызывает большие трудности. Такую ситуацию обусловливает ряд факторов, к основным можно отнести слабую увлеченность языком в школе, «перенесение математической модели связи на область естественно-языковой коммуникации как семиотического процесса», а также подготовку учителей иностранного языка в российских вузах, базирующуюся на «классическом наборе структуралистских догм и постулатов» $[18$, с. 75,79$]$. В результате на момент поступления в высшее учебное заведение уровень владения иностранным языком большинства абитуриентов неязыковых специальностей остается достаточно низким. Это подтверждает, в частности, входное тестирование абитуриентов по английскому языку, проводимое в Тюменском государственном университете (ТюмГУ). В связи с этим возникает необходимость использования на занятиях по английскому языку такого метода, который удовлетворял бы требованиям ком- 
муникативного подхода в обучении, минимизировал бы возможные трудности при говорении и способствовал бы формированию основных составляющих коммуникативной компетенции. В данной работе авторы предлагают рассмотреть ассоциативно-проектный метод в качестве одного из возможных способов решения поставленной задачи.

Цель данной работы заключается в описании ассоциативно-проектного метода и его применения на занятиях по английскому языку у студентов неязыковых специальностей для преодоления основных барьеров при говорении и формирования четырех основных составляющих иноязычной коммуникативной компетенции (языковой, речевой, социолингвистической и социокультурной).

Для достижения поставленной цели необходимо решить следующие теоретические и практические задачи:

1) установить основные трудности в овладении студентами неязыковых специальностей навыками говорения на английском языке;

2) описать ассоциативно-проектный метод, его составляющие, целесообразность применения у студентов неязыковых специальностей и апробировать его на занятиях по английскому языку в нескольких группах студентов, уровень владения английским языком которых варьируется от Elementary (элементарный) до Intermediate Low (средний низкий);

3) установить эффективность применения ассоциативно-проектного метода в преодолении основных барьеров при говорении на английском языке.

Исследование проходило в три этапа. Этапы исследования напрямую коррелируются с поставленными задачами.

Этап 1. Анкетирование студентов неязыковых специальностей и определение основных коммуникативных барьеров при говорении на английском языке.

Анализ отечественной научно-методической литературы показал, что основные трудности, препятствующие студенту в успешном овладении говорению на иностранном языке, содержат объективные и субъективные барьеры. Объективные барьеры отражают внешнюю, независимую от обучающегося ситуацию, например недостаточное материальное обеспечение дисциплины или большая наполняемость групп. Субъективные барьеры, напротив, связаны с объемом лингвистических, страноведческих и других знаний обучающегося, а также с его личностными качествами. В эту группу можно отнести, например, маленький словарный запас на иностранном языке или дискомфорт в общении.

На основании полученных данных мы подготовили анкету, которая включала один вопрос: Что из перечисленного в бо́льшей степени препятствует Вашему свободному говорению на английском языке? Обязательным условием данной анкеты была возможность выбора только одного варианта ответа. Такое ограничение является, по нашему мнению, необходимым для чистоты эксперимента. Говорение как вид деятельности, обеспечивающий коммуникацию, основывается на сложной совокупности навыков говорящего и внешней ситуации, поэтому все перечисленные в анкете пункты так или иначе препятствуют осуществлению коммуникации. Нам было необходимо установить первостепенную и, возможно, сопутствующие трудности при говорении. Опросный лист также предполагал возможность записи своего варианта ответа на тот случай, если какой-либо из коммуникативных барьеров не был учтен нами.

Таким образом, в список возможных трудностей при говорении на английском языке вошли следующие:

1. Нехватка видео-, аудио- и других материалов к изучаемым темам.

2. Большая наполняемость групп.

3. Отсутствие языковой практики у преподавателя.

4. Ваша низкая мотивация к изучению английского языка. 
Кукарская Г. Н., Пахомова В. М, Трифонова И. С. Развитие иноязычной коммуникативной...

5. Дискомфорт в общении, низкий уровень развития Ваших коммуникативных умений при личном общении.

6. Дефицит Вашего словарного запаса на английском языке.

7. Боязнь сделать ошибки и подвергнуть себя критике со стороны обучающихся и преподавателя.

8. Отсутствие у Вас достаточных фоновых знаний по обсуждаемой теме.

9. Недостаточное количество часов английского языка, предусмотренных учебным планом.

В опросе приняли участие 97 студентов ТюмГУ, обучающихся на разных курсах неязыковых специальностей с уровнем владения английским языком от Elementary (элементарный) до Intermediate Low (средний низкий). Анкетирование носило анонимный характер для создания более комфортной ситуации опроса и мотивирования участников на честные ответы.

Итак, бо́льшая часть респондентов (46 человек, что составляет почти 50 \% всех участников опроса) выделила дефицит словарного запаса на английском языке в качестве основной трудности, препятствующей свободному говорению на иностранном языке. Дискомфорт в общении, низкий уровень развития коммуникативных умений при личном общении и боязнь сделать ошибки, подвергнуть себя критике со стороны обучающихся и преподавателя в качестве основных трудностей отметили почти одинаковое количество опрошенных, 12 и 13 человек соответственно. Первый, четвертый и восьмой пункты анкеты (по шесть человек на каждый пункт) обозначили 18 человек: нехватка видео-, аудио- и других материалов к изучаемым темам, низкая мотивация к изучению английского языка, отсутствие достаточных фоновых знаний по обсуждаемой теме. Три студента выделили второй пункт (большая наполняемость групn), по одному респонденту отметили отсутствие языковой практики у преподавателя и недостаточное количество часов иностранного языка, предусмотренных учебным планом. Десятый пункт анкеты давал возможность респондентам написать свои ответы. Этим пунктом воспользовались три человека, которые отметили следующие трудности: 1 - нехватка времени на изучение английского языка в связи с большой академической нагрузкой; 2 - отсутствие занятий с носителем английского языка; 3 - недостаточное знание грамматики.

Схематически результаты проведенного опроса можно представить в виде диаграммы.

Трудности, препятствующие говорению на английском языке
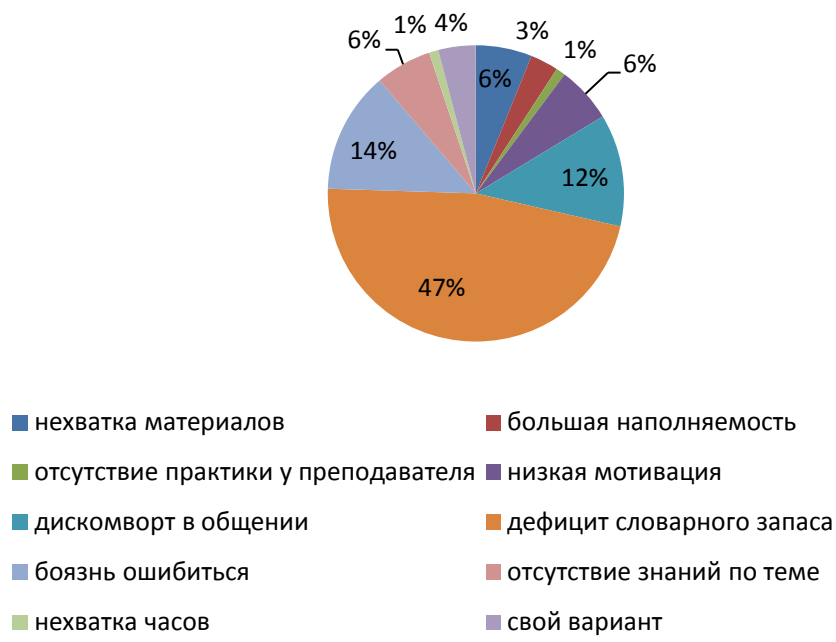

Результаты анкетирования студентов ТюмГУ 
Этап 2. Ассоииативно-проектный метод, его составляющие и изелесообразность применения у студентов неязыковых специальностей.

Ассоциативно-проектный метод основывается на взаимосвязанном применении двух методов: ассоциативного и проектного на занятиях по английскому языку. Оба этих метода в педагогике считаются нетрадиционными, в то же время эффективными при изучении новой лексики на иностранном языке и дальнейшем ее применении в языковой практике. Подтверждением этому могут служить появляющиеся в последнее десятилетие работы о необходимости и методических рекомендациях применения данных методов на занятиях по иностранному языку, например, таких авторов, как В. Г. Павленко [19], Г. Н. Монахова, Е. П. Зуева [20], Т. М. Рогожникова [21], Е. О. Розова [22], А. Я. Багрова [23] и др.

Традиционно в учебно-методической литературе овладение новой лексикой понимается как освоение некоторого лексического минимума по определенным темам, необходимого для формирования языкового компонента коммуникативной компетенции [24, 25]. Современные психолингвистические исследования, как отмечает в своем диссертационном исследовании Ю. Е. Лещенко, рассматривают индивидуальный словарный запас на иностранном языке в качестве «сложной многоярусной системы многократно пересекающихся ассоциативных полей, с помощью которых упорядочивается и хранится информация о предметах и явлениях окружающего мира и об обозначающих их вербальных единицах» [26, с. 3]. При этом ассоциацию принято определять как «возникшую в опыте индивида закономерную связь между двумя содержаниями сознания (ощущениями, представлениями, мыслями, чувствами и т. п.), которая выражается в том, что появление в сознании одного из содержаний влечет за собой и появление другого» [27, с. 26].

На сегодняшний день известны разные способы создания ассоциаций, например фонетические ассоциации, ситуативные ассоциации, рифмы, карточки-стикеры и т. д. В нашей работе мы использовали картинки на определенную тематику, которые вызывали визуальные наводящие ассоциации. Эти ассоциации были сконцентрированы не на отдельных словах, напротив, они связывались в сознании обучающегося с целым понятием или группой понятий. Например, картинка с бульдогом вызвала такие ассоциации, как «преданность», «решительность», «чистокровный», «породистый», «привязанность англичан к собакам», «любимая порода собак англичан», «Уинстон Черчилль» и т. д.

Несомненными достоинствами данного метода, по нашему мнению, является, вопервых, тот факт, что он не требует от обучающихся воспроизведения единственно верной фактической информации о картинке. Напротив, он дает возможность выразить все индивидуальные ассоциативные связи и тем самым делает процесс запоминания естественным, не требующим дополнительных усилий, что способствует формированию языковой компетенции студентов. Во-вторых, запоминаются не отдельные слова, а целые блоки информации, что обеспечивает формирование речевой компетенции студентов. При этом процесс запоминания также происходит естественно, в отличие от механического заучивания информации. Наконец, в-третьих, обучающиеся, имея возможность выражать свои мысли, чувствуют себя свободно при говорении, коммуникация легко поддерживается, что позволяет преодолевать одну из основных трудностей при говорении, а именно дискомфорт в общении.

Использование ассоциативного метода на занятиях по английскому языку облегчает применение метода проектов. Во-первых, к моменту создания проекта новая лексика по изучаемой теме уже закреплена и не раз применялась в ходе занятий, а теоретический материал подобран и проработан. Все эти факторы призваны минимизировать боязнь студентов сделать ошибку и подвергнуть себя критике со стороны обучающихся и преподавателя. 
Во-вторых, студенты готовы общаться и работать в команде. Сами же проекты на занятиях по иностранному языку, как отмечает Г. А. Забелина, являются эффективным способом, позволяющим «переключить внимание учащихся с формы высказывания на содержание и включиться в познание окружающего мира средствами иностранного языка», тем самым способствуют развитию речевой, социолингвистичекой и социокультурной компетенций [28, с. 3].

Описанный метод был апробирован на занятиях по английскому языку в трех группах разных языковых уровней и специальностей, а именно в смешанной группе первого курса, включающей такие специальности, как «Педагогическое образование: начальное образование и специальное (дефектологическое) образование»: логопедия (языковой уровень Еlеmentary (элементарный), количество человек - 16), группе третьего курса направления «История» (языковой уровень Pre-Intermediate (ниже среднего), количество человек - 16) и группе четвертого курса специальности «Педагогическое образование» с двумя профилями подготовки: история, иностранный язык (языковой уровень Intermediate Low (средний низкий), количество человек - 12). Всего в эксперименте приняли участие 44 студента неязыковых специальностей ТюмГУ.

Сроки проведения эксперимента определялись учебным графиком. Традиционно один семестр включает три модуля, каждый из которых длится 5-6 недель. В связи с этим экспериментальная серия занятий длилась в течение пяти недель, посвященных изучению одной темы. Занятия согласовывались с рабочими программами специальностей и включали следующие темы: Travelling and Holidays (Путешествия и каникулы), Great Historical Figures of Russia (Великие исторические личности России) и Britain and Its Political System (Великобритания и ее политическая система). Согласно учебным планам, количество часов в неделю на неязыковых направлениях варьируется от четырех до шести, что составляет два-три занятия в неделю. Для проведения эксперимента нам понадобилось одно занятие в неделю.

Перейдем к поэтапному описанию экспериментальной серии занятий по английскому языку с применением ассоциативно-проектного метода на примере группы четвертого курса специальности «Педагогическое образование с двумя профилями подготовки: история, иностранный язык» (языковой уровень Intermediate Low (средний низкий), количество человек - 12) по теме Britain and Its Political System (Великобритания и ее политическая система).

Прежде всего, необходимо условно разделить большую тему на более маленькие компоненты в соответствии с количеством отведенных недель. Например, по нашей теме получились следующие подтемы:

1) вводное занятие «Что Вы знаете о Великобритании?»;

2) «Монархия и члены королевской семьи»;

3) «Великие премьер-министры страны и их достижения»;

4) «Британский и Шотландский парламенты, Ассамблеи Уэльса и Северной Ирландии»;

5) финальное проектное занятие.

Далее в течение месяца каждую неделю (всего - 4) студенты в парах готовят материал для устного выступления в рамках одной из подтем по порядку. На само занятие они приносят картинку, связанную с их докладом. Например, на вводное занятие «Что Вы знаете о Великобритании?» студенты принесли картинки с телефонной будкой, такси, Букингемским дворцом, флагом Великобритании и т. д. Прежде чем начать свой доклад, студенты спрашивают группу, какие ассоциации у них вызывает та или иная картинка, о 
чем будет их доклад. Группа называет всевозможные ассоциации и предположения. Во время выступления докладчиков каждый студент фиксирует незнакомые ему слова, впоследствии их значение коллективно устанавливается. Завершающим этапом выступления докладчиков становится подготовленное ими упражнение для группы на закрепление услышанного материала. По форме это могут быть вопросы, викторины, кроссворды, карточки и т. д. После каждого такого занятия преподаватель собирает принесенные студентами картинки и хранит их до финального занятия. К пятой неделе таких картинок получается от 24 до 32.

На финальном занятии перед студентами ставится задача на основе имеющихся картинок оформить логически выстроенное выступление на пройденную тему, например о Великобритании и ее политическом устройстве. Группа делится на 4-5 подгрупп по 3-4 человека. Каждая подгруппа не глядя вытягивает 7-9 картинок из общего количества собранных преподавателем картинок. Таким образом, студенты заранее не знают, какие картинки им достанутся. После того как все картинки распределены, каждая группа приступает к оформлению своего проекта на заранее подготовленном ватмане и продумывает устное выступление таким образом, чтобы в нем приняли участие все члены группы и максимально была задействована пройденная лексика по теме. На подготовку отводится 30 минут (общая продолжительность занятия - 90 минут). В результате мы имеем 4-5 проектов со своим названием и логикой изложения. При этом во время защиты проектов может звучать как фактическая информация по пройденной теме, так и вызванные картинками ассоциации.

На защиту проектов отводится примерно 45-50 минут с учетом двухминутного выступления каждого докладчика и возможных вопросов от группы после презентации проекта. Оставшиеся 10-15 минут отводятся на рефлексию, во время которой еще раз проговаривается лексика по пройденной теме, а также студенты делятся впечатлениями о проделанной работе, дают оценку друг другу, озвучивают наиболее удачные моменты выступлений.

Следует отметить, что во время проведения таких занятий студенты постоянно работают в коллективе - от момента подготовки докладов в парах до презентации финального проекта в малых группах. Такая форма организации работы позволяет, на наш взгляд, решить целый ряд задач:

1) легче искать и готовить материал, поскольку есть возможность распределить задачи, роли и функции участников;

2) появляется больше идей, разных точек зрения, возможность разнопланового подхода;

3) внеаудиторное общение обучающихся позволяет сделать процесс коммуникации на занятиях более естественным, снизить уровень стеснения и дискомфорта;

4) при возникновении трудностей у одного из членов коллектива во время выступления у остальных участников есть возможность помочь ему и заполнить паузу своим выступлением.

Этап 3. Анкетирование студентов групп, в которых проводилась экспериментальная серия занятий, для установления эфрективности применения данного метода в преодолении трех установленных трудностей при коммуникации на иностранном языке.

В опросе приняли участие 44 студента ТюмГУ трех групп неязыковых специальностей разных языковых уровней - от Elementary (элементарный) до Intermediate Low (средний низкий), в которых в течение пяти недель занятия проводились с использованием ассоциативно-проектного метода.

Опросный лист включал три вопроса, соответствующие трем трудностям при говорении. Вопросы расположены в порядке убывания значимости - от самого важного к 
наименее важному. Значимость определялась результатами проведенного на первом этапе анкетирования. Каждый вопрос содержал три возможных варианта ответа в процентном соотношении. Опрос проводился анонимно. Ниже представлена разработанная анкета.

1. Насколько увеличился Ваш словарный запас на английском языке по изученной теме?

a. незначительно увеличился (от 0 до $33 \%$ );

b. достаточно увеличился (от 34 до $66 \%$ );

c. значительно увеличился (от 67 до $100 \%$ ).

2. Насколько прибавилось уверенности при говорении на английском языке в рамках изученной темы?

а. незначительно прибавилось (от 0 до $33 \%$ );

b. достаточно прибавилось (от 34 до $66 \%$ );

c. значительно прибавилось (от 67 до $100 \%$ ).

3. Насколько увеличился уровень развития Ваших коммуникативных умении и комфорта при личном общении?

а. незначительно увеличился (от 0 до $33 \%$ );

b. достаточно увеличился (от 34 до $66 \%$ );

c. значительно увеличился (от 67 до $100 \%$ ).

В результате бо́льшая часть респондентов (32 человека, что составляет более 70 \% всех участников опроса) при ответе на первый вопрос выбрала пункт «с» - значительно увеличился.

Пункт «b» (достаточно увеличился) выбрали 12 студентов.

Пункт «а» никто из опрошенных участников эксперимента не отметил.

При ответе на второй вопрос пункт «с» (значительно прибавилось) снова отметили большинство респондентов (24 человека, что составляет примерно 55 \%).

Пункт «b» (достаточно прибавилось) выбрали 16 человек (36 \%), а пункту «а» (незначительно прибавилось) отдали предпочтение 4 студента (9 \%).

В третьем вопросе лидирующее количество голосов набрал пункт «b» (достаточно увеличился), который отметили 30 респондентов (68 \%). Пункт «с» (значительно увеличился) выбрали 8 человек, 6 студентов остановились на пункте «а» (незначительно увеличился).

В результате первого этапа исследования с помощью метода анкетирования и впоследствии ранжирования полученных результатов были установлены основной барьер (дефицит словарного запаса) и две сопутствующие трудности (дискомфорт в общении, низкий уровень развития коммуникативных умений при личном общении и боязнь сделать ошибки, подвергнуть себя критике со стороны обучающихся и преподавателя), которые, по мнению студентов ТюмГУ с языковым уровнем от Elementary (элементарный) до Intermediate Low (средний низкий), препятствуют их свободному говорению на английском языке.

Дальнейшее исследование потребовало поисков метода, удовлетворяющего требованиям коммуникативного подхода в обучении, обеспечивающего формирование языковой, речевой, социолингвистической и социокультурной компетенций и способного минимизировать установленные в результате опроса студентов трудности в процессе коммуникации на английском языке. Авторы работы предлагают ассоциативно-проектный метод в качестве возможного метода решения поставленной задачи и применяют его на экспериментальной серии занятий по английскому языку в трех группах студентов неязыковых специальностей 
с языковыми уровнями Elementary (элементарный), Pre-Intermediate (ниже среднего) и Intermediate Low (средний низкий).

Заключительным этапом исследования стал еще один опрос студентов групп, в которых проводилась экспериментальная серия занятий. В основе предложенной анкеты - три наиболее значимые трудности при говорении на английском языке и степень их преодоления после применения ассоциативно-проектного метода. Результаты проведенного опроса оказались в значительной степени положительными, поскольку при ответе на два из трех предложенных вопросов, один из которых был основным и касался главной трудности, препятствующей свободному говорению на английском языке, большинство респондентов выбрали самую высокую позицию (от 67 до 100 \%). При ответе на последний вопрос участники опроса выбрали среднюю позицию (от 34 до 66 \%), что также можно рассматривать как положительный результат.

Таким образом, применение ассоциативно-проектного метода на занятиях по английскому языку, во-первых, облегчает процесс запоминания новой лексики на иностранном языке, параллельно развивая образное мышление; во-вторых, дает возможность развить языковую, речевую, социолингвистическую и социокультурную компетенции; в-третьих, способствует приобретению уверенности обучающихся в использовании иностранных слов и преодолению коммуникативных барьеров при говорении. Наконец, он соответствует общепризнанным этапам работы с лексикой (ознакомление, закрепление, употребление нового материала в речи) и удовлетворяет современной исследовательской тенденции образования.

\section{Список литературы}

1. Вятютнев М. Н. Коммуникативная направленность обучения русскому языку в зарубежных школах // Русский язык за рубежом. 1977. № 6. С. 38-45.

2. Таюрская Н. П. Иноязычная коммуникативная компетенция: зарубежный и российский опыт // Гуманитарный вектор. Серия: Педагогика. Психология. 2015. № 1 (41). С. 83-87.

3. Berger P. L. Many Globalizations: Cultural Diversity in the Contemporary World. Oxford: Oxford University Press, 2000. 385 p.

4. Borden George A. Constructs for a Theory of Human Communication // Communication Yearbook $1 /$ ed. by D. Brend Ruben. An Annual Review. Interpersonal Communication Association. New Brunswick; New Jersey, 1977. P. 89-97.

5. Бим И. Л. Место иностранного языка в системе общего среднего образования // Глядя в будущее. Первый советско-американский симпозиум по теоретическим проблемам преподавания и изучения иностранных языков. 17-21.10.1989. М.: Рема; МГЛУ, 1992. С. 9-18.

6. Гез Н. И. Методика обучения иностранным языкам: пособие для учителя. М.: АРКТИ, 2003. 189 с.

7. Елизарова Г. В. О природе социокультурной компетенции // Слово, предложение и текст как интерпретирующие системы. Studia Lingüistica 8. СПб.: Тригон, 1999. С. 274-281.

8. Зимняя И. А. Лингвопсихология речевой деятельности. Москва: Московский психолого-социальный институт; Воронеж: НПО «МОДЭК», 2001. 432 с.

9. Пассов Е. И. Контроль как методический феномен: генезис, сущность, функции (при коммуникативном методе обучения) // Контроль в обучении иностранным языкам: сб. ст. М., 1986. С. 89-107.

10. Savignon S. J. Communicative Competence: Theory and Classroom Practice. 2nd ed. New York: McGraw-Hill, 1997. $272 \mathrm{p}$.

11. Сафонова В. В. Социокультурный подход к обучению иностранному языку как специальности: дис. ... д-ра пед. наук. М., 1992. 228 с.

12. Hymes D. On Communicative Competence // Sociolinguistics. Harmondsworth Penguin, 1972. P. 269-293.

13. Щукин А. Н. Обучение иностранным языкам: теория и практика. М.: Филоматис, 2007. 480 с. 
14. Дуайе П. Проблема обучения лексике // Методика преподавания иностранных языков за рубежом. М.: Прогресс, $1967.440 \mathrm{c}$.

15. Bachman L. Fundamental Considerations in Language Testing. Oxford: Oxford University Press, 1990. 408 p.

16. Мильруд Р. П. Компетентность в изучении языка // Иностранные языки в школе. 2004. № 7. С. 30-37.

17. Гром Е. Н. Содержание и формы контроля уровня сформированности и иноязычной коммуникативной компетенции учащихся 10-11 классов школ с углубленным изучением иностранного языка: дис. ... канд. пед. наук. М., 1999.315 с.

18. Кравченко А. В., Паюнена М. В. Практика в плену у теории: почему так трудно научиться иностранному языку в школе // Вестник Томского государственного университета. Филология. 2018. № 56. С. 65-85.

19. Павленко В. Г. Ассоциативный метод обучения иностранного языка в неязыковом вузе // Современные научные исследования и инновации. 2016. № 8. URL: http://web.snauka.ru/issues/2016/08/70504 (дата обращения: 03.01.2020).

20. Монахова Г. Н., Зуева Е. П. Метод ассоциаций при изучении немецкого языка как второго иностранного языка // Педагогический опыт: теория, методика, практика. 2016. № 1 (6). С. 103-105.

21. Рогожникова Т. М. Ассоциация как инструмент для изучения языков: учеб. пособие для аспирантов. Уфа: Уфимский гос. авиационный технический ун-т, 2019. 81 с.

22. Розова Е. О. Использование проектной методики при обучении иностранному языку // LINGUA MOBILIS. 2012. № 1 (34). С. 162-167.

23. Багрова А. Я. Проектный метод в обучении иностранным языкам // Вестник Московского института лингвистики. 2015. № 1. С. 12-17.

24. Пассов Е. И. Основы методики обучения иностранным языкам. М.: Русский язык, 1977. 211 с.

25. Рогова Г. В. Методика обучения английскому языку (на английском языке): учеб. пособие для студ. пед. ин-тов. М.: Просвещение, 1983.350 с.

26. Лещенко Ю. Е. Становление лексикона билингва (по данным ассоциативного эксперимента): автореф. дис. ... канд. филол. наук. Пермь, 2005. 20 с.

27. Горошко Е. И. Языковое сознание: гендерная парадигма. СПб.: Алетейя, 2006.329 с.

28. Забелина Г. А. Метод проектов в системе высшего профессионального образования: автореф. дис. ... канд. пед. наук. М., 2009. 29 с.

Кукарская Галина Николаевна, старший преподаватель, Тюменский государственный университет (ул. Володарского, 6, Тюмень, Россия, 625003). E-mail: g.n.kukarskaya@utmn.ru

Пахомова Вера Михайловна, старший преподаватель, Тюменский государственный университет (ул. Володарского, 6, Тюмень, Россия, 625003). E-mail: v.m.pakhomova@utmn.ru

Трифонова Ирина Сергеевна, кандидат филологических наук, старший преподаватель, Тюменский государственный университет (ул. Володарского, 6, Тюмень, Россия, 625003). E-mail: i.s.trifonova@utmn.ru

Материал поступил в редакциюю 17.01.2020.

DOI 10.23951/2307-6127-2020-2-100-112

\section{DEVELOPING FOREIGN LANGUAGE COMMUNICATIVE COMPETENCE OF NON-LINGUISTIC STUDENTS USING THE ASSOCIATION-PROJECT METHOD}

\section{G. N. Kukarskaya, V. M. Pakhomova, I. S. Trifonova}

\section{University of Tyumen, Tyumen, Russian Federation}

The present article outlines the fundamental tendency in foreign language teaching - a communicative one. Effective teaching methods are necessary to make non-linguistic students 
sound naturally and confidently. The specific objective of this study is to identify and overcome the main barriers in speaking English using a method that develops foreign communicative competence. The association-project method is considered to become a possible solution of the problem. The study is carried out in three stages. The first stage involves a questionnaire of non-linguistic students about the main difficulties in speaking English. Ninety seven students of University of Tyumen took part in this survey. On the second stage we give English lessons using the association-project method in three nonlinguistic groups. Forty four students with Elementary, Pre-Intermediate and Intermediate Low English Levels were involved. And finally these students take a questionnaire about the effectiveness of the association-project method in overcoming the main difficulties in speaking English. At first questioning of non-linguistic students and following ranking of the obtained data made it possible to identify three main difficulties in speaking English. These communicative barriers are both linguistic and extralinguistic in nature. The use of the association-project method in English classes allowed to overcome these difficulties significantly. The final questionnaire of non-linguistic students proves this fact. The association-project method is a combination of two fairly new and relevant methods (association and project methods) used in foreign language teaching. It meets modern educational requirements, develops the key components of foreign communicative competence (linguistic, discursive, sociolinguistic and sociocultural) and helps to cope with the main barriers in speaking a foreign language.

Keywords: foreign language communicative competence, communicative barriers, association-project method, association, questionnaire.

\section{References}

1. Vyatyutnev M. N. Kommunikativnaya napravlennost' obucheniya russkomu yazyku v zarubezhnykh shkolakh [The communicative focus of Russian language teaching in foreign schools]. Russkiy yazyk za rubezhom - Russian Language Abroad, 1977, no. 6, pp. 38-45 (in Russian).

2. Tayurskaya N. P. Inoyazychnaya kommunikativnaya kompetentsiya: zarubezhnyy i rossiyskiy opyt [Foreign language communicative competence: foreign and Russian experience]. Gumanitarnyy vektor. Ser. Pedagogika. Psikhologiya - Humanitarian Vector. Series Pedagogy, Psychology, 2015, no. 1 (41), pp. $83-87$ (in Russian).

3. Berger P. L. Many Globalizations: Cultural Diversity in the Contemporary World. Oxford: Oxford University Press, 2000. 385 p.

4. Borden George A. Constructs for a Theory of Human Communication. Communication Yearbook 1. Ed. by D. Brend Ruben. An Annual Review. Interpersonal Communication Association. New Brunswick-New Jersey, 1977. Pp. 89-97.

5. Bim I. L. Mesto inostrannogo yazyka $\mathrm{v}$ sisteme obshchego srednego obrazovaniya [The place of a foreign language in the secondary education system]. Glyadya $v$ budushcheye. Pervyy sovetsko-amerikanskiy simpozium po teoreticheskim problemam prepodavaniya i izucheniya inostrannykh yazykov 17-21.10.1989 [Looking to the future. The first Soviet-American symposium on theoretical problems of teaching and learning foreign languages 17-21.10.1989]. Moscow, Rema; MSLU Publ., 1992. Pp. 9-18 (in Russian).

6. Gez N. I. Metodika obucheniya inostrannym yazykam: posobiye dlya uchitelya [Methods of teaching foreign languages: a manual for a teacher]. Moscow, ARKTI Publ., 2003. 189 p. (in Russian).

7. Elizarova G. V. O prirode sotsiokul'turnoy kompetentsii [The nature of sociocultural competence]. Slovo, predlozheniye i tekst kak interpretiruyushchiye sistemy. Studia Lingüistica 8 [Word, sentence and text as interpreting systems]. Saint Petersburg, Trigon Publ., 1999. Pp. 274-281 (in Russian).

8. Zimnyaya I. A. Lingvopsikhologiya rechevoy deyatel'nosti [Linguopsychology of speech activity]. Moscow, MSUPE Publ., Voronezh, «MODEK» Publ., 2001. 432 p. (in Russian).

9. Passov E. I. Kontrol' kak metodicheskiy fenomen: genezis, sushchnost', funktsii (pri kommunikativnom metode obucheniya) [Control as a methodological phenomenon: genesis, essence, functions (within a communicative teaching method)]. Kontrol'v obuchenii inostrannym yazykam: sbornik statey [Control in teaching foreign languages: collected works]. Moscow, 1986. Pp. 89-107 (in Russian). 
10. Savignon S. J. Communicative Competence: Theory and Classroom Practice. 2nd ed. New York: McGraw-Hill, 1997. $272 \mathrm{p}$.

11. Safonova V. V. Sotsiokul'turnyy podkhod k obucheniyu inostrannomu yazyku kak spetsial'nosti. Dis. d-ra ped. $n a u k$ [Sociocultural approach to teaching a foreign language as a specialty. Dis. of doct. of ped. sci.]. Moscow, 1992. 228 p. (in Russian).

12. Hymes D. On Communicative Competence. In: J.B. Pride and J. Holmes (eds.), Sociolinguistics. Harmondsworth, Penguin, 1972. Pp. 269-293.

13. Shchukin A. N. Obucheniye inostrannym yazykam: teoriya i praktika [Teaching foreign languages: theory and practice]. Moscow, Filomatis Publ., 2007. 480 p. (in Russian).

14. Duaye P. Problema obucheniya leksike [The problem of vocabulary teaching]. Metodika prepodavaniya inostrannykh yazykov za rubezhom [Methods of teaching foreign languages abroad]. Moscow, Progress Publ., 1967. 440 p. (in Russian).

15. Bachman L. Fundamental Considerations in Language Testing. Oxford: Oxford University Press, 1990. 408 p.

16. Mil'rud R. P. Kompetentnost'v izuchenii yazyka [Competence in language learning]. Inostrannye yazyki v shkole, 2004, no. 7, pp. 30-37 (in Russian).

17. Grom E. N. Soderzhaniye i formy kontrolya urovnya sformirovannosti inoyazychnoy kommunikativnoy kompetentsii uchashchikhsya 10-11 klassov shkol s uglublennym izucheniyem inostrannogo yazyka. Dis. kand. ped. nauk [The content and forms of control of foreign language communicative competence of 10-11 grades students at schools with advanced curriculum in foreign languages. Dis. of cand. ped. sci.]. Moscow, 1999. 315 p. (in Russian).

18. Kravchenko A. V., Payunena M. V. Praktika v plenu u teorii: pochemu tak trudno nauchit'sya inostrannomu yazyku $\mathrm{v}$ shkole [Practice in captivity to theory: why it is so difficult to learn a foreign language at school]. Vestnik Tomskogo gosudarstvennogo universiteta. Filologiya - Tomsk State University Journal of Philology, 2018, no. 56, pp. 65-85 (in Russian).

19. Pavlenko V. G. Assotsiativnyy metod obucheniya inostrannogo yazyka v neyazykovom vuze [The associative method of a foreign language teaching in a non-linguistic university]. Sovremennye nauchnye issledovaniya $i$ innovatsii - Modern scientific researches and innovations, 2016, no. 8 (in Russian). URL: http://web.snauka.ru/issues/2016/08/70504 (accessed 3 January 2020).

20. Monakhova G. N., Zuyeva E. P. Metod assotsiatsiy pri izuchenii nemetskogo yazyka kak vtorogo inostrannogo yazyka [The method of associations in the study of German as a second foreign language]. Pedagogicheskiy opyt: teoriya, metodika, praktika, 2016, no. 1 (6), pp. 103-105 (in Russian).

21. Rogozhnikova T. M. Assotsiatsiya kak instrument dlya izucheniya yazykov: uchebnoye posobiye dlya aspirantov po napravleniyu podgotovki 45.06.01 Yazykoznaniye i literaturovedeniye [Association as a tool for learning languages: a textbook for graduate students in the training program 45.06.01 Linguistics and literary criticism]. Ufa, USATU Publ., 2019. 81 p. (in Russian).

22. Rozova E. O. Ispol'zovaniye proyektnoy metodiki pri obuchenii inostrannomu yazyku [The use of project methods in foreign language teaching]. LINGUA MOBILIS, 2012, no. 1 (34), pp. 162-167 (in Russian).

23. Bagrova A. Ya. Proyektnyy metod v obuchenii inostrannym yazykam [The method of projects in training in foreign languages]. Vestnik Moskovskogo instituta lingvistiki - Vestnik of Moscow State Linguistic University, 2015, no. 1, pp. 12-17 (in Russian).

24. Passov E. I. Osnovy metodiki obucheniya inostrannym yazykam [Fundamentals of teaching foreign languages]. Moscow, Russkiy yazyk Publ., 1977. 211 p (in Russian).

25. Rogova G. V. Metodika obucheniya angliyskomu yazyku (na angliyskom yazyke): uchebnoe posobiye dlya studentov pedagogicheskikh institutov [Methods of teaching English (in English): a study guide for students of pedagogical institutes]. Moscow, Prosveshcheniye Publ., 1983. 350 p. (in Russian).

26. Leshchenko Yu. E. Stanovleniye leksikona bilingva (po dannym assotsiativnogo eksperimenta). Avtoref. dis. kand. filol. nauk [Formation of the bilingual lexicon (according to an associative experiment). Abstract of thesis cand. philol. sci.]. Perm, 2005. 20 p. (in Russian).

27. Goroshko E. I. Yazykovoye soznaniye: gendernaya paradigma [Linguistic consciousness: gender paradigm]. SaintPetersburg, Aleteyya Publ., 2006. 329 p. (in Russian).

28. Zabelina G. A. Metod proyektov v sisteme vysshego professional'nogo obrazovaniya. Avtoref. dis. kand. ped. nauk [Project method in the system of higher professional education. Abstract of thesis cand. ped. sci.]. Moscow, 2009. 29 p (in Russian). 
Kukarskaya G. N., University of Tyumen (ul. Volodarskogo, 6, Tyumen, Russian Federation, 625003). E-mail: g.n.kukarskaya@utmn.ru

Pakhomova V. M., University of Tyumen (ul. Volodarskogo, 6, Tyumen, Russian Federation, 625003).E-mail: v.m.pakhomova@utmn.ru

Trifonova I. S., University of Tyumen (ul. Volodarskogo, 6, Tyumen, Russian Federation, 625003). E-mail: i.s.trifonova@utmn.ru 